Universal Decimal Classification (UDC) 616-053.32-092.11-037

\title{
RISK FACTORS AND PREDICTION CHART OF VIOLATIONS OF HEALTH OF THE ONE-YEAR-OLDS BORN WITH VERY LOW AND EXTREMELY LOW BIRTH WEIGHT
}

\section{O.M. Filkina, E.A. Vorobieva, N.V. Dolotova, E.A. Matveeva, A.I. Malyshkina, N.D. Gadzhimuradova}

FGBI "Ivanovo Research Institute of Maternity and Childhood named after V.N Gorodkov" of the Russian Federation Ministry of Health, 20, Pobedy st. Ivanovo, 153045, Russian Federation

The study revealed biological and social risk factors for the formation of life of the one-year-olds such as the low length, deficit of body weight, delay of mental development, frequent acute respiratory infections, the formation of cerebral palsy in children born with very low and extremely low birth weight. In identifying risk factors and prognostic drafting tables the method of sequential mathematical analysis of Wald has been used. It was found that the greatest influence on the formation of these health disorders in children with birth weight less than $1500 \mathrm{~g}$ have the biological risk factors - health status and age of the mother, during pregnancy and childbirth, the child's health condition in the neonatal period. An algorithm for predicting the data of health disorders in the child's admission with a birth weight less than 1500 grams under the supervision of the district pediatrician.

Key words: risk factors, forecasting health disorders, children with very low and extremely low birth weight.

Nowadays a special attention is given to researches dedicated to health of children born with very low and extremely low birth weight. The importance of the problem has increased greatly over the last few years as new criteria for giving birth to a viable fetus recommended by the World Health Organization have been implemented in the Russian Federation. Due to intensive care development we can see a significant rise in survival rate for premature children born with birth weight lower than 1500 grams $[4,5,11]$. Now the rate of infants with extremely low birth weight (less than 1000 grams) equals to $0.2 \%$ and with very low birth weight (from 1000 to 1500 grams) - to $0.8 \%$ [5]. Among premature children the rate of infants with extremely low boy weight has grown up to $5.6 \%$, and with very low birth weight - to $10.5 \%[5,11]$.

Prematurity and low birth weight determine further development and health of a child to a great extent $[2,8,9,16]$. Premature children with very low and extremely low birth weight belong to a category with high risks of central nervous system affection, incapacitating pathology and persistent non-incapacitating disorders evolvement. Therefore an extremely cautious prediction of their development is required $[1,2,4,5,7,8,9,13]$. Prediction plays a very important role in children health formation control as it helps not only to detect risk factors but also to define positive ones and it allows us to work out prevention techniques

(c) Filkina O.M., Vorobieva E.A., Dolotova N.V., Matveeva E.A., Malyshkina A.I., Gadzhimuradova N.D., 2016

Filkina Olga Mikhailovna - MD, Professor, Honored Doctor of the Russian Federation; Head of the child health department (e-mail: omfilkina@mail.ru; phone: + 7 (4932) 33-70-55).

Vorobeva Elena Anatolievna - Doctor of Medical Sciences; a leading researcher at the Department of Child Health (e-mail: ivniideti@mail.ru; phone: + 7 (4932) 33-70-55).

Dolotova Natalia Vasilievna - Candidate of Medical Sciences; Senior Researcher of child health department (e-mail: ivniideti@mail.ru; phone: 7 (4932) 33-70-55).

Matveeva Ekaterina Alexandrovna - Candidate of Medical Sciences; catamnesis pediatrician's office, Scientific Secretary (e-mail: ivniideti@ mail.ru; phone: + 7 (4932) 33-83-20).

Malyshkina Anna Ivanovna - doctor of medical sciences, associate professor; Director (e-mail: ivniimid@ivnet.ru; phone: +7 (4932) 33-62-63).

Gadzhimuradova Nadezhda Dzhabrailovna - post-graduate of the department of child health (e-mail: ivniideti@mail.ru; phone: + 7 (4932) 33-70-55). 
aimed at positive safety factors prevailing $[6,14]$. Hence we should regularly estimate the influence of both separate factors and their aggregates $[6,12$, 15]. Prevention is the most promising sphere in children health care but it can be efficient only with early detection of children who run the risk of somatic health disorders, physical retardation, and neurologic and behavioral retardation $[3,6,10,15$, 17].

The purpose of the research is to identify risk factors and to work out a prediction algorithm which helps to detect physical disorders, neurologic and behavioral retardation, frequent acute respiratory diseases, and infantile cerebral paralysis in children born with very low and extremely low birth weight over the first year of life.

Data and techniques. We have carried out clinical research which comprised 100 premature one-year-old children born with birth weight lower than 1500 grams. We have also collected the necessary biological and social data from child development reports (form No. 112/1-y), questionnaires filled in by parents, and parents' interviews. We have used Wald sequential mathematic analysis when determining risk factors for most frequent health disorders and creating a prediction table. After we have proved discrepancy accuracy in occurrence frequency for a factor of interest in groups of children with health disorders (short body length, weight deficiency, neurological and behavioral retardation, frequent acute respiratory diseases, and infantile cerebral paralysis) and groups of children without them, we have calculated predictive ratios for each factor level. A predictive ratio has been calculated as $\mathrm{PR}=10 \mathrm{lg}$ $(\mathrm{P} 1 / \mathrm{P} 2)$ when a factor occurred, and $\mathrm{PR}=10 \mathrm{lg}(1$ - P1/1 - P2) when a factor was absent, where P1 and P2 are factors occurrence frequencies in groups being compared. A positive result value was the evidence of unfavorable prediction.

Results and discussion. When we examined a one-year-old children born with birth weight lower than 1500 grams we defined that more than a half of such children (58\%) had physical disorders namely weight deficiency (40\%) and short body length $(34 \%)$, as well as both these disorders. $20 \%$ had moderate and $41 \%$ had marked neurological and behavioral retardation. 19\% suffered from infantile cerebral paralysis. When we analysed the frequency of acute respiratory diseases occurring during the first year of life we found out that $24 \%$ of children born with body weight lower than 1500 grams often had such diseases.

On the basis of social and biological data analysis we have determined significant risk factors which can cause physical disorders (short body length and weight deficiency), neurological and behavioral retardation, frequent acute respiratory diseases, and infantile cerebral paralysis.

Among significant biological risk factors we can name unfavourable professional factors in a mother's life and their duration for more than 5 years before conception; a mother suffering from urinary tract pathology; threat of miscarriage; fetoplacental insufficiency; oligoamnios; 3 degree cerebral ischemia; a child having two-side intraventricular hemorrhage in neonatal period; a child being on artificial pulmonary ventilation for more than 7 days; bronchopulmonary dysplasia; fetal infection; a child having bowels dysbacteriosis. Social risk factors include marital status at the moment of conception (common marriage); a mother's social status (employed); a father having secondary special education; a father's social status (employed); a father working irregular hours without days off.

Biological factors having the greatest influence on weight deficiency are the age of a mother (older than 35); pregnancy being the third or more; a mother having acute respiratory diseases during pregnancy; fetal growth retardation syndrome. Social factors having the greatest influence on weight deficiency include a mother's level of education, a mother's social status (unemployed), a father working irregular hours.

Neurological and behavioral retardation of children born with birth weight lower than 1500 grams is mostly caused by such biological factors as the age of mother (older than 35); a mother suffering from acute and chronic inflammatory diseases of genital system; induced abortion of early pregnancy; birth weight lower than 1000 grams; APGAR rates 1-3; extremely poor condition of a newborn; breast feeding absence. And social factors include parents' workplaces.

We have determined the following biological factors as having the greatest influence on frequency of acute respiratory diseases for children born with birth weight lower than 1500 grams. They are duration of unfavourable professional factors in a mother's life for more than 5 years before conception; a mother suffering from cardiovascular disorders, a mother suffering from acute and chronic inflammatory diseases of genital system; threat of 
miscarriage. Social factors are the age of mother when getting married and a father's education.

Infantile cerebral paralysis is greatly determined by such biological factors as therapeutic abortions and miscarriages in past history of a mother; $1^{\text {st }}$ minute APGAR rates $1-3$, extremely poor condition of a newborn; 3 degree cerebral ischemia; periventricular leikomalacia; congenital malformation; movement disorders syndrome.

Risk factors causing short body length, neurological and behavioral retardation, frequent acute respiratory diseases, and infantile cerebral paralysis in children with birth weight lower than 1500 grams by the age of 1 year

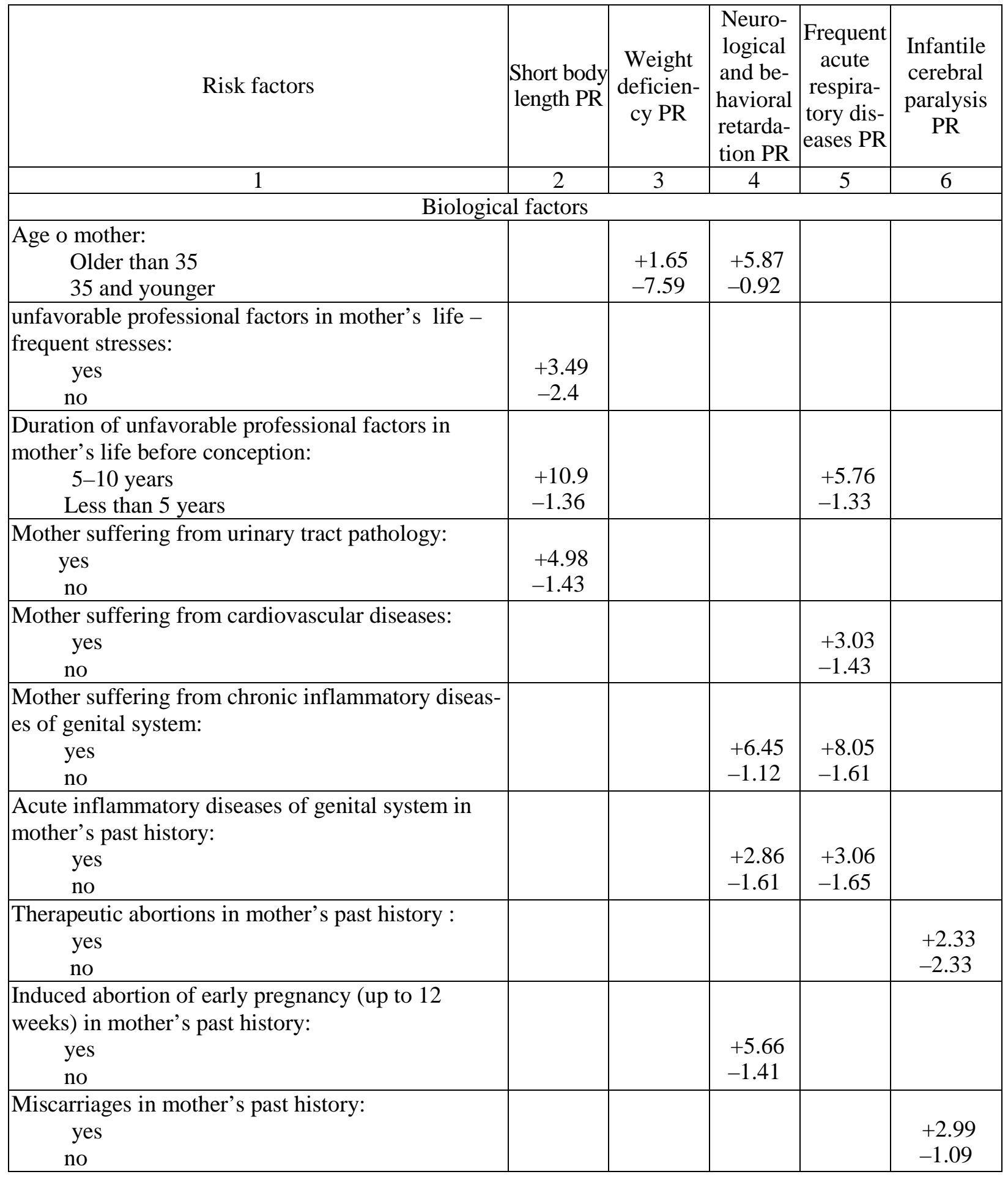




\begin{tabular}{|c|c|c|c|c|c|}
\hline $\begin{array}{l}\text { The ordinal number of this pregnancy: } \\
\text { second } \\
\text { third and more }\end{array}$ & & $\begin{array}{l}-6.54 \\
+1.16\end{array}$ & & & \\
\hline $\begin{array}{l}\text { Mother suffering from acute respiratory diseases } \\
\text { during this pregnancy: } \\
\text { yes } \\
\text { no }\end{array}$ & & $\begin{array}{r}+3.87 \\
-3.61\end{array}$ & & & \\
\hline $\begin{array}{l}\text { Miscarriage threat for this pregnancy: } \\
\text { yes } \\
\text { no }\end{array}$ & $\begin{array}{l}+2.18 \\
-3.12\end{array}$ & & & $\begin{array}{c}+2.10 \\
-4.51\end{array}$ & \\
\hline $\begin{array}{l}\text { Fetoplacental insufficiency during this pregnancy: } \\
\text { yes } \\
\text { no }\end{array}$ & $\begin{array}{r}+5.0 \\
-4.51\end{array}$ & & & & \\
\hline $\begin{array}{l}\text { Oligoamnios during this pregnancy: } \\
\text { yes } \\
\text { no }\end{array}$ & $\begin{array}{l}+6.8 \\
-0.7\end{array}$ & & & & \\
\hline \multicolumn{6}{|c|}{ Table 1 continued } \\
\hline 1 & 2 & 3 & 4 & 5 & 6 \\
\hline $\begin{array}{l}\text { Fetal pathology during this pregnancy - arrested } \\
\text { fetal development syndrome: } \\
\text { yes } \\
\text { no }\end{array}$ & & $\begin{array}{l}+5.63 \\
-1.57\end{array}$ & & & \\
\hline $\begin{array}{l}\text { Prematurity of } 28 \text { weeks and less: } \\
\text { yes } \\
\text { no }\end{array}$ & & & & & $\begin{array}{l}+3.28 \\
-2.01 \\
\end{array}$ \\
\hline $\begin{array}{l}\text { Birth weight: } \\
\text { less than } 1000 \text { grams } \\
1000-1500 \text { grams } \\
\end{array}$ & & & $\begin{array}{c}+5.74 \\
-3.09\end{array}$ & & \\
\hline $\begin{array}{l}\text { First minute APGAR rate: } \\
1-3 \text { points } \\
\text { more than } 3 \text { points }\end{array}$ & & & $\begin{array}{c}+4.41 \\
-1.26\end{array}$ & & $\begin{array}{l}+2.65 \\
-5.36\end{array}$ \\
\hline $\begin{array}{l}\text { Newborn overall condition: } \\
\text { poor } \\
\text { extremely poor }\end{array}$ & & & $\begin{array}{l}-3.19 \\
+3.67\end{array}$ & & $\begin{array}{l}-4.78 \\
+3.69\end{array}$ \\
\hline $\begin{array}{l}\text { Child suffering from } 3 \text { degree cerebral ischemia in } \\
\text { neonatal period: } \\
\text { yes } \\
\text { no }\end{array}$ & $\begin{array}{l}+2.15 \\
-2.14\end{array}$ & & & & $\begin{array}{c}+5.56 \\
-6.86\end{array}$ \\
\hline $\begin{array}{l}\text { Child having two-sided intraventricular hemorrhage } \\
\text { in neonatal period: } \\
\text { yes } \\
\text { no }\end{array}$ & $\begin{array}{r}+2.8 \\
-1.56\end{array}$ & & & & \\
\hline $\begin{array}{l}\text { Periventricular leikomalacia: } \\
\text { yes } \\
\text { no }\end{array}$ & & & & & $\begin{array}{l}+5.17 \\
-2.49\end{array}$ \\
\hline $\begin{array}{l}\text { Child being on artificial pulmonary ventilation: } \\
\text { more than } 7 \text { days } \\
\text { less than } 7 \text { days }\end{array}$ & $\begin{array}{c}+8.56 \\
-3.84\end{array}$ & & & & \\
\hline $\begin{array}{l}\text { Child having bronchopulmonary dysplasia in neona- } \\
\text { tal period: } \\
\text { yes } \\
\text { no }\end{array}$ & $\begin{array}{l}+11.8 \\
-1.26\end{array}$ & & & & \\
\hline
\end{tabular}




\begin{tabular}{|c|c|c|c|c|c|}
\hline $\begin{array}{l}\text { Fetal infections: } \\
\text { yes } \\
\text { no }\end{array}$ & $\begin{array}{c}+11.0 \\
-1.1\end{array}$ & & & & \\
\hline $\begin{array}{l}\text { Congenital malformations: } \\
\text { yes } \\
\text { no }\end{array}$ & & & & & $\begin{array}{c}+2.68 \\
-1.79\end{array}$ \\
\hline $\begin{array}{l}\text { Child having bowels dysbacteriosis in neonatal peri- } \\
\text { od: } \\
\quad \text { yes } \\
\text { no }\end{array}$ & $\begin{array}{l}+1.66 \\
-4.63\end{array}$ & & & & \\
\hline $\begin{array}{l}\text { Breast feeding: } \\
\text { yes } \\
\text { no }\end{array}$ & & & $\begin{array}{c}+2.86 \\
-1.61\end{array}$ & & \\
\hline $\begin{array}{l}\text { Child having movement disorders syndrome: } \\
\text { yes } \\
\text { no }\end{array}$ & & & & & $\begin{array}{r}+5.09 \\
-3.97\end{array}$ \\
\hline \multicolumn{6}{|c|}{\begin{tabular}{|l|l} 
& Social factors \\
\end{tabular}} \\
\hline $\begin{array}{l}\text { Marital status at the moment of conception: } \\
\text { common marriage } \\
\text { registered marriage }\end{array}$ & $\begin{array}{l}+5.12 \\
-2.94\end{array}$ & & & & \\
\hline $\begin{array}{l}\text { Age of mother when getting married: } \\
20-30 \text { years } \\
\text { younger than } 20 \text { years }\end{array}$ & & & & $\begin{array}{l}-8.25 \\
+3.39\end{array}$ & \\
\hline $\begin{array}{l}\text { Mother having specialized secondary education: } \\
\text { yes } \\
\text { no }\end{array}$ & & $\begin{array}{l}-3.12 \\
+1.87\end{array}$ & & & \\
\hline $\begin{array}{l}\text { Mother's social status: } \\
\text { employed } \\
\text { housewife }\end{array}$ & $\begin{array}{l}+0.83 \\
-5.13\end{array}$ & & & & \\
\hline
\end{tabular}

\begin{tabular}{|c|c|c|c|c|c|}
\hline \multicolumn{6}{|c|}{ Table 1 ending } \\
\hline 1 & 2 & 3 & 4 & 5 & 6 \\
\hline $\begin{array}{l}\text { Mother's social status: } \\
\text { employed } \\
\text { unemployed }\end{array}$ & & $\begin{array}{l}-1.29 \\
+6.09\end{array}$ & & & \\
\hline $\begin{array}{l}\text { Mother's occupation: } \\
\text { economy } \\
\text { trade. light industry }\end{array}$ & & & $\begin{array}{l}-5.59 \\
+0.94\end{array}$ & & \\
\hline $\begin{array}{l}\text { Father's education: } \\
\text { specialized secondary } \\
\text { unfinished higher }\end{array}$ & $\begin{array}{l}+2.22 \\
-4.77\end{array}$ & & & $\begin{array}{l}+4.69 \\
-3.37\end{array}$ & \\
\hline $\begin{array}{l}\text { Father's social status: } \\
\text { blue-collar worker } \\
\text { white-collar worker }\end{array}$ & $\begin{array}{l}+2.17 \\
7.27\end{array}$ & & & & \\
\hline $\begin{array}{l}\text { Father's working hours: } \\
\text { irregular } \\
\text { regular }\end{array}$ & $\begin{array}{l}+3.39 \\
-3.19\end{array}$ & $\begin{array}{l}+3.39 \\
-3.19\end{array}$ & & & \\
\hline $\begin{array}{l}\text { Father having unfavourable professional factors - } \\
\text { absence of days off } \\
\text { yes } \\
\text { no }\end{array}$ & $\begin{array}{l}+3.63 \\
-1.34\end{array}$ & & & & \\
\hline $\begin{array}{l}\text { Father's sphere of occupation - construction work: } \\
\text { yes }\end{array}$ & & & +9.18 & & \\
\hline
\end{tabular}


Therefore we can state that such biological risk factors as a mother and a child health, pregnancy and delivery course, and a child health in neonatal period have the greatest significance for occurrence of short body length, weight deficiency, neurological and behavioral retardation, frequent acute respiratory diseases, and infantile cerebral paralysis in children with birth weight lower than 1500 grams.

When a premature child born with birth weight lower than 1500 grams starts to receive medical supervision by a district pediatrician, a medical nurse identifies presence or absence of social and biological risk factors that can cause short body length, neurological and behavioral retardation, frequent acute respiratory diseases, and infantile cerebral paralysis. She can do it by interviewing parents and collecting data from a child development report and maternity hospital records.

We suggest a predictive table (table 1) which can be used to sum up the predictive ratios (PR) values for health risk factors identified for a child for each health disorders (short body length, neurological and behavioral retardation, frequent acute respiratory diseases, and infantile cerebral paralysis).

The total value of predictive ratios sum determines the prediction. Predictive threshold (PT) value allows us to estimate degree of confidence for health disorders evolvement by the end of the first year (short body length, weight deficiency, neurological and behavioral retardation, frequent acute respiratory diseases, and infantile cerebral paralysis). This value was calculated by Wald sequential mathematic analysis. We admitted the $5 \%$ mistakes probability and defined the predictive threshold for such disorders by the end of the first year as +13 being their presence and -13 being their absence.

If the predictive ratios sum equals to or exceeds +13 the prediction is unfavourable and we predict presence of short body length (predictive ratios sum in the $2^{\text {nd }}$ column), weight deficiency (predictive ratios sum in the $3^{\text {rd }}$ column), neuro- logical and behavioral retardation (predictive ratios sum in the $4^{\text {th }}$ column), frequent acute respiratory diseases (predictive ratios sum in the $5^{\text {th }}$ column) and infantile cerebral paralysis (predictive ratios sum in the $6^{\text {th }}$ column) by the end of the first year.

If the predictive ratios sum equals to or is less than -13 the prediction is favourable and we predict absence of such health disorders.

If the predictive ratios sum is between +12 and -12 we can state that prediction is uncertain and we don't have enough data to formulate a certain one; therefore such children should be under constant supervision.

Children for whom prediction is unfavourable are included into risk group of health disorders evolvement and pediatricians prescribe prevention activities for them which can lower the risk of these disorders evolvement. The necessity to identify infantile cerebral paralysis risk groups among children born with birth weight lower than 1500 grams is determined by the possibility to use differentiated approach to their treatment and early rehabilitation. These activities can lower the risk of this incapacitating pathology evolvement.

\section{Conclusion.}

To sum up, we can say that we have identified biological and social risk factors that can cause short body length, weight deficiency, neurological and behavioral retardation, frequent acute respiratory diseases, and infantile cerebral paralysis in children born with low and extremely low birth weight by the end of the first year of their life. Such biological factors as the age and health of a mother, pregnancy and delivery course, and a child condition in neonatal period have the greatest influence on such health disorders evolvement. We have also worked out prediction algorithm that is aimed at prediction of such health disorders when a child born with birth weight lower than 1500 grams starts to receive medical observation by a district pediatrician.

\section{References}

1. Andrejuk O.G. Osobennosti sostojanija zdorov'ja, prognozirovanie ego narushenij u detej, rozhdennyh s massoj tela menee 1500 grammov, na pervom godu zhizni: avtoref. dis. ... kand. med. Nauk [Characteristics of health status, its prediction in babies weighing less than 1500 grams on the $1^{\text {st }}$ year of life: extended abstract of dissertation. ... Candidate of medical science]. Ivanovo, 2011, 22 p. 
2. Antonova L.K., Bliznecova E.A. Katamnez detej s jekstremal'no nizkoj massoj tela pri rozhdenii (obzor literatury) [Catamnesis of children with extremely low birth weight (literature review)]. Verhnevolzhskij medicinskij zhurnal, 2015, no. 1, pp. 4-7.

3. Baranov A.A. Profilakticheskaja pediatrija: rukovodstvo dlja vrachej [Preventive pediatrics: a guide for physicians]. Moscow, Sojuz pediatrov Rossii, 2012, 692 p.

4. Baranov A.A., Albitsky V. Yu., Ivanova A.A., Terletskaya R.N., Kosova S.A. Tendencii zabolevaemosti i sostojanie zdorov'ja detskogo naselenija Rossijskoj Federacii [Trends and the health status of the child population of the russian federation]. Rossijskij pediatricheskij zhurnal, 2012, no. 6, pp. 4-9.

5. Baranov A.A., Namazova-Baranova L.S., Belyaeva I.A., Yatsyk G.V., Bombardirova E.P., Zayniddinova R.S., Smirnov I.E. Neonatal'nyj stacionar II jetapa «Mat' i ditja» kak mediko-organizacionnaja tehnologija sovershenstvovanija sistemy medicinskoj pomoshhi novorozhdennym [Stage II Neonatal hospital "Mother and Child" as a health organizational technology for the improvement of the system of medical care for newborns]. Rossijskij pediatricheskij zhurnal, 2014, no. 6, pp. 16-22.

6. Bocharova E.A., Sidorov P.I., Solov'ev A.G. Mediko-biologicheskie faktory riska formirovanija psihorechevoj patologii v detskom vozraste [Speech and mental pathology forming in children - medical and biologic risk factors]. Pediatrija, 2002, no. 1, pp. 91-93.

7. Lazurenko S.B. Analiz struktury patologicheskih sostojanij novorozhdennyh detej, privodjashhih k invalidizacii, $\mathrm{i}$ ih otdalennye posledstvija [Analysis of the pattern of neonatal morbidities resulting in disability and their late sequels]. Rossijskij pediatricheskij zhurnal, 2009, no. 1, pp. 49-51.

8. Malyshkina A.I., Fil'kina O.M., Pesikin O.N., Nazarov S.B., Dolotova N.V. Regional'naja model' katamnesticheskogo nabljudenija na pervom godu zhizni detej s ochen' nizkoj i jekstremal'no nizkoj massoj tela pri rozhdenii [The regional model of catamnesis monitoring of children of the first year of life with very low and extremely low body mass at birth]. Zdravoohranenie Rossijskoj Federacii, 2014, Vol. 58, no. 6, pp. 53-56.

9. Merzlova N.B., Kurnosov Y.V., Vinokurova L.N., Baturin V.I. Katamnez detej, rozhdennyh s ochen' nizkoj i jekstremal'no nizkoj massoj tela [Catamnesis of child which were born with very low baby weight and extremely low baby weight]. Fundamental'nye issledovanija, 2013, no. 3, pp. 121-125.

10. Baranov A.A., Namazova-Baranova L.S., Lazurenko. S.B., Il'in A.G., Jacyk G.V., Konova S.R., Pavlova N.N., Barinov M.P. Ocenka riska vozniknovenija u novorozhdennyh i mladencev narushenij nervno-psihicheskogo razvitija: metodicheskie rekomendacii dlja pediatrov [Risk assessment of the mental disorders' development in neonates and infants: guidelines for pediatricians]. Moscow, Pediatr, 2016, 36 p.

11. Namazovoj-Baranovoj L.S. Principy jetapnogo vyhazhivanija nedonoshennyh detej [Principles of sequential nursing of the preterm infants]. Moscow, Pediatr, 2013, 240 p.

12. Rumjancev A.M., Timakova M.V., Chechel'nickaja S.M. Nabljudenie za razvitiem i sostojaniem zdorov'ja detej: rukovodstvo dlja vrachej [Monitoring the development and health status of children: a guide for physicians]. Moscow, Medpraktika, 2004, 388 p.

13. Sakharova E.S., Keshishian E.S., Alyamovskaya G.A. Nevrologicheskie ishody u nedonoshennyh detej k trehletnemu vozrastu (nabljudavshiesja v specializirovannom centre) [Neurological outcomes in preterm infants by age three (observed in a specialized center)]. Medicinskij sovet. Pediatrija, 2015, no. 1, pp. 50-53.

14. Stupak V.S., Podvornaja E.V., Filkina O.M., Pykhtina L.A. Rezul'taty issledovanija social'nobiologicheskih faktorov riska razvitija perinatal'noj patologii u detej pervyh treh let zhizni [Results of the study of social and biological risk factors for perinatal pathology in children during the first three years of life]. Jakutskij medicinskij zhurnal, 2013, no. 4, pp. 41-44.

15. Tonkova-Jampol'skaja R.V. Sostojanie zdorov'ja detej s uchetom faktorov ante- i postnatal'nogo riska [Health status of children, taking into account factors of the ante- and postnatal risk]. Rossijskij pediatricheskij zhurnal, 2002, no. 1, pp. 61-62.

16. Filkina O.M., Dolotova N.V, Andreyuk O.G., Vorobyova E.A. Zabolevaemost' nedonoshennyh detej, rodivshihsja s ochen' nizkoj i jekstremal'no nizkoj massoj tela, k koncu pervogo goda zhizni [Morbidity of premature infants which were born with low and extremely low body mass]. Vestnik Ivanovskoj medicinskoj akademii, 2010, Vol. 15, no. 3, pp. 49-53.

17. Fil'kina O.M., Pykhtina L.A., Vorob'yeva E.A., Kocherova O.Yu., Dolotova N.V., Shanina T.G. Faktory riska otklonenij fizicheskogo razvitija u detej rannego vozrasta s perinatal'nymi porazhenijami central'noj nervnoj sistemy [The risk factors of dapartures in physical development in children of early age with perinatal affection of central nervous system]. Lechenie i profilaktika, 2015, no. 1 (13), pp. 16-19. 